\title{
Creativity and Narrative Writing in L2 Classrooms: Comparing Individual and Paired Task Performance
}

\author{
Reza Zabihi \& Mohsen Rezazadeh \\ University of Isfahan, Isfahan, Iran \\ Hossein Vahid Dastjerdi \\ Islamic Azad University, Shahreza Branch, Shahreza, Iran
}

Article received 28 October 2012, accepted 14 February 2013, final version received 7 July 2013

\begin{abstract}
The study reported in this paper aimed at examining the role of creativity in L2 learners' individual and collaborative written narrative task performance, with the sociocultural theory of mind as a frame of reference. To this end, a sample of 92 intermediate university EFL learners in Isfahan, Iran, participated in this study. The participants were homogenized and divided into two groups: one group performing individually and the other group performing collaboratively. The study involved the measurement of the learners' creativity using the Abbreviated Torrance Test for Adults (ATTA) in terms of features of fluency, elaboration, flexibility and originality as well as the elicitation of learners' individual and collaborative written narrative task performance in terms of three measures of task performance, i.e. Complexity, Accuracy, and Fluency (CAF). The results showed (a) significant advantages regarding the CAF of collaborative writings in comparison with that of individual writers in terms of accuracy; (b) significant correlations between creative fluency and learners' fluent performance in individual, but not paired, task performance; and (c) negative relationships between creative originality and learners' fluent performance in both individual and paired task performance. The implications of the study are discussed.
\end{abstract}

\section{Introduction}

It is now well accepted that creativity is related to learners' writing abilities (Sak, 2004; Scanlon, 2006; Smith, Paradice \& Smith, 2000) in the sense that some of the features relevant to the writing ability — such as free communication of ideas (Torrance, 1992), the consideration of the human individual (Harrington, Block \& Block, 1983) and self-disclosure (Amabile, 1996)somehow overlap with those features which are expected to enhance creativity. Moreover, with the emergence of communicative and task-based methods in language teaching, which required that learners use their imagination, creativity has been a focus of recent language teaching research (Albert, 2007). Several studies in SLA research have considered the relationship 
between creativity and oral task performance (Albert, 2007; Albert \& Kormos, 2011) although some studies have been criticized for only considering individual task performance during written tasks (Pishghadam \& Javdan Mehr, 2011), ignoring the fact that ideas develop through joint participation, that ideas are discussed, favored and disfavored, as well as shared in a dialogical process (Rojas-Drummond, Albarran \& Littleton, 2008).

Along these lines of dialogical process, the study reported in this paper builds upon Vygotsky's (1978) sociocultural theory of mind, whereby peer collaboration and social interaction are expected to be more effective than individual learning on students' performance. In plain language, granted the fact that creative writing undertakings such as narrative tasks require that learners take advantage of imaginative powers and that learners' performance tends to be enhanced in collaborative learning environments (Cole, 1996), we shall analyze how learners' collaborative task performance might pertain to the complexity, accuracy and fluency of their writings. To reflect on the comparative nature of the present study, learners' collaboratively produced texts were compared with individual performances of a second group.

In what follows, we provide the readers with an overview of the concept of creativity and its perceived and conceived relation to SLA tasks, concluding that unlike a fair amount of research done on the role of creativity in oral task performance, the role of creativity in SLA writing tasks has somewhat been ignored. Next, having touched upon Vygotsky's sociocultural theory, we hypothesize that writing tasks performed within a collaborative framework might have greater chances of enjoying higher rates of complexity, accuracy and fluency than those performed alone. This brings us to the conclusion that creativity can have differential effects on the output that the learners provide while performing individually or in pairs.

\section{Theoretical Background and Review of Literature}

Creativity pertains to one's ability to look at things from novel and original perspectives, to transfer obtained experience to new situations, to think in unconventional and idiosyncratic ways and to use novel approaches to problem solving and making original things (Duffy, 1998). It involves evaluative ability, problem sensitivity, production fluency, idea novelty, mind flexibility, synthesizing and analyzing capability, conceptual structure complexity and reorganization or redefinition of organized wholes (Guilford, 1950); it also comprises divergent 
thinking, i.e. the ability of an individual to generate several novel and unique ideas in response to a problem, as a core cognitive element of creativity (Guilford, 1959). Most importantly, creativity is related to the notion of 'idea production' comprising several components such as ideational fluency, naming facility, associational fluency, expressional fluency, word fluency, sensitivity to problems, originality/creativity, figural fluency, and figural flexibility (Carroll, 1993). Being different from other notions like recognition, identification, comparison and selection, idea production is usually evaluated by tasks requiring students to produce a series of responses promptly.

The narrative genre is one of the areas where the study of creativity might provide fruitful implications. For decades, it has been an inseparable part of social sciences and linguistics research (Ozyildirim, 2009). Similarly, narrative tasks are a well-established and frequently studied task type (e.g., Foster \& Skehan, 1996; Robinson, 1995) in language learning. These tasks, due to their open-ended nature, require that learners recite a fictional or real account of an event or an experience sequentially (Justice, Bowles, Pence, \& Gosse, 2010), paving the way for the activation of learners' imagination. To this extent, students are typically required to narrate a story in response to some visual stimuli such as picture strips or short films. When it comes to the role of creativity, narrative written tasks seem to be quite relevant because they usually offer visual stimuli and require that the learner reconstruct a story in written form.

Because writing is an unlimited process with no prescheduled end, it is conducive in its goal to 'creative design' (Sharples, 1999), which in turn is grounded in individuals' creative thinking abilities (Vass, 2007). With that in mind, it was found quite relevant to establish the role of creativity in learners' narrative written task performance, focusing on the differential role of creativity in the features of Complexity, Accuracy, and Fluency (herein CAF) of individually and collaboratively written texts. The present study attempts to make a connection between creativity in writing activity and collaboration, based on the sociocultural theory of mind which highlights the role of mediation in the enhancement of learning.

The study revolves around the importance of collaboration, creativity and the coconstruction of narrative written texts, given the fact that learning is accomplished dialogically through the interactions among learners and teachers, while engaging in the joint construction of knowledge. From this perspective, learning is a process of engaging in shared activities 
involving the acquisition and the transformation of "both the organizing conceptual theories and the patterns of discourse used by particular reasoning communities" (Resnick, Pontecorvo \& Saljo, 1997, p. 4).

In a similar manner, this co-construction of knowledge takes place when individuals take part in collective practices mediated by several cultural artefacts, tools and signs (Rogoff, Turkanis \& Bartlett, 2001), with 'language' playing a crucial role as a mediator of activity. Language is a cultural, social, and psychological tool through which shared knowledge is developed and the processes and content of people's thoughts are shaped (Vygotsky, 1978). Vygotsky contended that social interactions forge some of the most important cognitive capabilities; hence, individuals' engagement in joint activities and tasks brings into being new understandings and ways of thinking —which bring to mind the definitions of creativity discussed above. The process of meaning-making is thus a both an interpersonal and intrapersonal process (Wegerif \& Mercer, 1997). As Wertsch (1991) has pointed out, it is through the co-construction of meaning that several views or 'heteroglossia' (in Bakhtin's (1981) words), might emerge; and, as is argued here, the emergence of multiple perspectives may also be mediated by learners' creativity.

\section{The Present Study}

Given that writing is an unlimited process with no pre-arranged limit or end, it may be a unique opportunity for eliciting individuals' creative thinking abilities (Vass, 2007). A narrative task was selected to examine the differential role of creativity in the CAF of individually and collaboratively-written texts, framed within the sociocultural theory of fostering the expansion of social interaction and peer- as well as teacher-mediated performance. In short, granted the fact that creative writing undertakings such as narrative tasks require that learners take advantage of imaginative powers and that learners' performance tends to be enhanced in collaborative learning environments (Cole, 1996), this study analyzes how learners' collaborative task performance might pertain to the complexity, accuracy and fluency of their writings and subsequently, creativity. To reflect on the comparative nature of the present study, learners' collaboratively produced texts were compared with individual performances of a second group to discern which 
tasks promoted more creative responses. This study, therefore, aims at answering the following three research questions:

1. Does collaboration have any effect on the CAF of written narrative task performance of Iranian intermediate EFL Learners?

2. Is there a relationship between creativity and the CAF of individual L2 written narrative tasks?

3. Is there a relationship between creativity and the CAF of paired L2 written narrative tasks?

\section{Method}

Ninety-two male (30.4\%) and female (69.6\%) intermediate learners majoring in English Language and Literature in University of Isfahan, Iran voluntarily took part in the study. Their ages ranged from 18 to 26 and their native language was Persian. Based on a version of an Oxford Placement Test (OPT), intermediate-level learners were selected for the study. The reason for selecting intermediate learners was that we needed learners who could develop a whole story by composing narratives of at least 250 words. Considering the low number of advanced and upperintermediate learners, we had to pick intermediate learners. The test contained 60 multiple choice items, and it was used to enable the researchers to control learners' language proficiency. This test consisted of grammar (20 items), vocabulary (20 items), reading comprehension (20 items), together with a writing section. The allotted time for answering the questions was 45 minutes. After correcting the tests, among 140 learners who took the test, 92 learners were selected as the intermediate group based on the OPT manual.

Given that the participants of this study were Iranian young adults, the Abbreviated Torrance Test for Adults (ATTA, Goff \& Torrance, 2002) was selected for measuring creativity. The ATTA is a shortened version of the Torrance Test of Creative Thinking (TTCT) and has been commonly used by researchers (e.g., Kharkhurin, 2008; Lin, Hsu, Chen, \& Wang, 2011; Meintjes \& Grosser, 2010; Wang, 2011). The test measures the number of ideas the learner can produce within a particular time period (fluency), the extent to which these ideas are unique (originality), the number of details that the learner can add to the original idea (elaboration) and how many varieties of ideas can be produced for solving a problem (flexibility). It comprises three tests: one verbal and two figural tests. In order to solve problems or communicate ideas, 
within a particular time period, the learners are expected to recognize problems, make guesses, and generate ideas by writing phrases or sentences and by drawing pictures. The Creativity Index is ranked with seven levels, whose values range from 1 to 7 ( $1=$ Minimal; $2=$ Low; $3=$ Below Average; 4 = Average; 5 = Above Average; $6=$ High; $7=$ Substantial). It takes about 15 minutes to complete.

Moreover, the reliability and validity of the TTCT have been well established (Kim, 2006; Runco, Dow \& Smith, 2006). Goff and Torrance (2002) have reported a reliability of 0.90 for the Creativity Index, using a KR-21 reliability coefficient. Besides, they have found reliability coefficients ranging from 0.38 to 0.84 for the subscales of creativity.

The participants were randomly assigned to individual $(\mathrm{N}=32)$ and collaborative $(\mathrm{N}=60)$ groups. Both groups of learners were then assigned a narrative task. The collaborative and individual task performances differed in the written task in the sense that, in the collaborative group, learners could take advantage of, and scaffold, one another's imaginative powers and, hence, their performance were expected to be enhanced. In such a collaborative learning environment, members of the pairs were allowed to add, remove, or modify one another's written expressions. In doing so, they were asked to freely discuss, negotiate and come to agreement on what should be included in their writings.

The task required learners to narrate a story based on a number of pictures in the form of a cartoon strip, provided as visual cues for the plot. Thirty minutes were allotted to the activity. A written narrative task was chosen, as this task type seemed to easily lend itself to eliciting the creativity of learners. The reliability of these measures was determined by two trained raters who coded the data for all the learners in each group. An interrater reliability check on the two raters was calculated on each of the rating categories and yielded coefficients ranging from .66 to .85.

Further, Complexity, Accuracy and Fluency (CAF) have been regarded as the underlying constituents of L2 proficiency and performance by many scholars (cf. Skehan, 2009; Ellis \& Yuan, 2004; Larsen-Freeman, 2009; and Norris \& Ortega, 2009). Ellis (2003) defined complexity as "the extent to which the language produced in performing a task is elaborate and varied" (p. 340); later on, he and his colleague Yuan referred to complexity as the degree to which learners are willing to take risks to use the cutting edge of their linguistic knowledge which can finally result in the process of restructuring (Ellis \& Barkhuizen, 2005). Accuracy, on 
the other hand, pertains to the degree of divergence from a specific norm which can be conceived of as errors (Wolfe-Quintero, Inagaki, \& Kim, 1998). Finally, fluency relates to learners' general language proficiency, characterized by impressions of ease, expressiveness, and smoothness in speech or writing (Hilton, 2008).

Considering the fact that "a full picture of language development in L2 writing can only be obtained by engaging fluency, accuracy, and complexity measures at various linguistic levels" (Lu, 2011, p. 38), we took advantage of these three measures to evaluate the quality of learners' written productions. In doing so, all written outputs were firstly coded for T-units and clauses. A T-unit is characterized as "one main clause plus whatever subordinate clauses happen to be attached to or embedded within it" (Hunt, 1966, p. 735). For the measurement of complexity and accuracy, the writings had to be analyzed for clauses wherein independent and dependent clauses were distinguished. In the present study, dependent clauses were those which comprised a finite or a non-finite verb and at least one additional clause element such as subject, object, complement or adverbial.

The CAF of learners' performance was operationalized in the following manner: Complexity was measured through calculating the proportion of clauses to T-units, which according to Foster and Skehan (1996) is a reliable measure of subordination correlating well with other complexity measures. Besides, the T-unit seemed to be ideal for intermediate or advanced written data which are typically formed in full clauses and sentences (Norris \& Ortega, 2009). Still another measure of complexity used in the present study is the proportion of dependent clauses to clauses $(\mathrm{DC} / \mathrm{C})$, which investigates the degree of embedding in the text

(Wolfe-Quintero et al., 1998); Moreover, for assessing accuracy, two general measures of accuracy were used as percentages: the proportion of error-free T-units to all T-units (EFT/T) and the proportion of error-free clauses to all clauses $(\mathrm{EFC} / \mathrm{C})$. Finally, we used the measure suggested by Wigglesworth and Storch (2009), i.e. the average number of words, T-units and clauses per text, to estimate the fluency of learners' performance.

\section{Results}


In order to compare individual and paired L2 written task performance, the first statistical test concerned the effect of collaboration on the dependent variables for the writing task. ANOVAs were carried out on each dependent variable in order to determine for which measures there were significant differences. The minimum alpha for confirmation of the research hypotheses was .05. The descriptive data for the three fluency, complexity, and accuracy measures together with a summary of the results from the ANOVAs are displayed in three separate tables.

Two variables were utilized to measure complex language used in participants' written products. As shown in Table 1, the mean scores for the two complexity measures are almost the same for both individual and paired written texts. The results of ANOVAs, presented in Table 1, reveal that none of the two complexity measures for any of the planning conditions have any significant differences (clauses per T-unit, $F=.593, p>0.05$; percentage of dependent clauses, $F$ $=.001, p>0.05)$. Therefore, based on the results obtained in Table 1, no significant differences were found in the way in which the individuals performed the tasks compared to the pairs.

Table 1. Measures of Complexity

\begin{tabular}{ll|r|r|r|r|r}
\hline & Writing & Mean & Std. Deviation & F & Sig. & $\begin{array}{c}\text { Partial Eta } \\
\text { Squared }\end{array}$ \\
\hline \multirow{2}{*}{ Clauses per T-unit } & Individuals & 1.8193 & .34940 & & & \\
& Pairs & 1.8752 & .31285 & .593 & .444 & .007 \\
& Total & 1.8519 & .32769 & & & \\
Dep. & Individuals & 38.2864 & 10.88802 & & & .000 \\
ClausesPercentage & Pairs & 38.2252 & 9.52122 & .001 & .978 & .000 \\
& Total & 38.2507 & 10.04934 & & & \\
\hline
\end{tabular}

Accuracy was measured in global units: error free T-units percentage and error free clauses percentage. As illustrated in Table 2, pairs had the highest means on both measures of accuracy. The ANOVAs show that there are overall statistically significant differences for the two variables of accuracy (error-free T-units percentage, $F=15.409, p<.0001$ ) and more error free clauses percentage $(F=28.772, p<.0001)$, implying that collaborative writing had a positive correlation with accuracy. That is to say, the opportunity for collaborative writing resulted in more accurate written production. 
Table 2. Measures of Accuracy

\begin{tabular}{ll|r|r|r|r|c}
\hline & Writing & Mean & Std. Deviation & F & Sig. & $\begin{array}{c}\text { Partial Eta } \\
\text { Squared }\end{array}$ \\
\hline \multirow{2}{*}{ Error Free T- } & Individuals & 48.6777 & 20.12132 & & & \\
unitsPercentage & Pairs & 63.4683 & 14.43574 & 15.409 & .000 & .158 \\
& Total & 57.3055 & 18.44387 & & & \\
\hline Error Free Clauses & Individuals & 66.5948 & 12.88617 & & & \\
Percentage & Pairs & 79.0867 & 8.45819 & 28.772 & .000 & .260 \\
& Total & 73.8817 & 12.15647 & & & \\
\hline
\end{tabular}

As shown in Table 3, the mean scores for all three measures of fluency are higher in the individual planned condition, indicating that individuals tended to compose longer texts than subjects who composed collaboratively. The results of ANOVAs, illustrated in Table 3, show that there is a statistically significant difference between individual and paired written performance regarding fluency measures (words per text: $F=4.216, p<0.05$; T-units per text $F$ $=9.769, p<0.01$; clauses per texts $F=7.404, p<0.01$ ). All measures of fluency are significantly higher for individuals indicating that in terms of fluency (i.e. length of production), individual writing resulted in longer texts.

Table 3. Measures of Fluency

\begin{tabular}{ll|r|r|r|r|c}
\hline & Writing & Mean & Std. Deviation & F & Sig. & $\begin{array}{c}\text { Partial Eta } \\
\text { Squared }\end{array}$ \\
\hline \multirow{3}{*}{ NO of Words } & Individuals & 170.29 & 35.750 & & & \\
& Pairs & 155.86 & 34.273 & 4.216 & .043 & .075 \\
& Total & 161.87 & 35.413 & & & \\
\hline \multirow{2}{*}{ NO of T-units } & Individuals & 15.46 & 4.083 & & & .106 \\
& Pairs & 13.00 & 3.122 & 9.769 & .002 &. \\
\hline \multirow{3}{*}{ NO of Clauses } & Total & 14.02 & 3.735 & & & \\
& Individuals & 27.49 & 6.386 & & & .083 \\
& Pairs & 23.98 & 5.387 & 7.404 & .008 & \\
\hline
\end{tabular}

Moreover, a Pearson product-moment correlation coefficient was computed to assess the relationship between creativity and the $\mathrm{CAF}$ of individual narrative task performance. The three measure of task performance (complexity, accuracy, and fluency) were correlated with four measures of creativity (fluency, originality, elaboration, and flexibility) as well as the total creativity of learners. As shown in Table 4, significant positive correlations were observed between creative fluency and the three fluency measures of the narrative task (number of words $r$ 
$=.51, p<0.05$; number of T-units $r=.59, p<0.05$; number of clauses $r=.57, p<0.05$ ). Besides, all three fluency measures correlated positively with the total creativity score (number of words $r$ $=.52, p<0.05$; number of T-units $r=.41, p<0.05$; number of clauses $r=.54, p<0.05$ ).

Correlation analysis shows that number of words $(r=-.55, p<0.05)$ and number of clauses $(r=-.41, p<0.05)$ are negatively correlated with the creative originality. However, the other measure of fluency is also negatively correlated with originality; it is not shown to be significant $(r=-.34, p>0.05)$. In other words, students who generated more ideas (creative fluency) within the set time on the creativity test produced longer texts (fluency of the text) and those who scored highly on the originality component of the creativity test wrote shorter narrations.

Results with regard to complexity measures, illustrated in Table 4, reveal that the syntactic complexity of essays produced by individuals was related to creative elaboration, since the number of clauses per $\mathrm{T}$-unit $(\mathrm{r}=.39, \mathrm{p}<0.05)$ and dependent clauses percentage $(\mathrm{r}=.41, \mathrm{p}<$ 0.05) correlated positively with the elaboration measure of the creativity test. Finally, there was no significant correlation between accuracy and any of the creativity scores.

Table 4. Correlations between creativity and individual task performance

\begin{tabular}{|c|c|c|c|c|c|c|c|}
\hline \multicolumn{3}{|c|}{ Individual Essays } & $\begin{array}{l}\text { Creative } \\
\text { Fluency }\end{array}$ & $\begin{array}{c}\text { Creative } \\
\text { Originality }\end{array}$ & $\begin{array}{c}\text { Creative } \\
\text { Elaboration }\end{array}$ & $\begin{array}{l}\text { Creative } \\
\text { Flexibility }\end{array}$ & $\begin{array}{c}\text { Creativity } \\
\text { Index }\end{array}$ \\
\hline \multirow{9}{*}{ Fluency } & \multirow{3}{*}{ NO of Words } & Pearson Correlation & $.510^{*}$ & $-.551^{*}$ & .328 & .194 & $.528^{*}$ \\
\hline & & Sig. (2-tailed) & .037 & .022 & .198 & .456 & .030 \\
\hline & & $\mathrm{N}$ & 32 & 32 & 32 & 32 & 32 \\
\hline & \multirow{3}{*}{ NO of T-units } & Pearson Correlation & $.590^{*}$ & -.345 & .276 & .311 & $.413^{*}$ \\
\hline & & Sig. (2-tailed) & .013 & .175 & .283 & .224 & .019 \\
\hline & & $\mathrm{N}$ & 32 & 32 & 32 & 32 & 32 \\
\hline & \multirow{3}{*}{ NO of Clauses } & Pearson Correlation & $.571^{*}$ & $-.416^{*}$ & .424 & .162 & $.548^{*}$ \\
\hline & & Sig. (2-tailed) & .017 & .047 & .089 & .533 & .025 \\
\hline & & $\mathrm{N}$ & 32 & 32 & 32 & 32 & 32 \\
\hline \multirow{6}{*}{ Complexity } & \multirow{3}{*}{ Clauses per T-unit } & Pearson Correlation & .313 & .176 & $.397^{*}$ & .384 & .407 \\
\hline & & Sig. (2-tailed) & .221 & .499 & .036 & .128 & .105 \\
\hline & & $\mathrm{N}$ & 32 & 32 & 32 & 32 & 32 \\
\hline & \multirow{3}{*}{$\begin{array}{l}\text { Dep. Clauses } \\
\text { Percentage }\end{array}$} & Pearson Correlation & .268 & -.180 & $.413^{*}$ & .063 & .438 \\
\hline & & Sig. (2-tailed) & .299 & .490 & .047 & .811 & .078 \\
\hline & & $\mathrm{N}$ & 32 & 32 & 32 & 32 & 32 \\
\hline \multirow{6}{*}{ Accuracy } & \multirow{3}{*}{$\begin{array}{l}\text { Error Free Clauses } \\
\text { Percentage }\end{array}$} & Pearson Correlation & -.060 & .212 & .435 & -.257 & .050 \\
\hline & & Sig. (2-tailed) & .818 & .414 & .081 & .320 & .848 \\
\hline & & $\mathrm{N}$ & 32 & 32 & 32 & 32 & 32 \\
\hline & \multirow{3}{*}{$\begin{array}{l}\text { Error Free T-units } \\
\text { Percentage }\end{array}$} & Pearson Correlation & .204 & .399 & .032 & .209 & .234 \\
\hline & & Sig. (2-tailed) & .433 & .112 & .903 & .422 & .367 \\
\hline & & $\mathrm{N}$ & 32 & 32 & 32 & 32 & 32 \\
\hline
\end{tabular}


Table 4. Correlations between creativity and individual task performance

\begin{tabular}{|c|c|c|c|c|c|c|c|}
\hline \multicolumn{3}{|c|}{ Individual Essays } & $\begin{array}{l}\text { Creative } \\
\text { Fluency }\end{array}$ & $\begin{array}{c}\text { Creative } \\
\text { Originality }\end{array}$ & $\begin{array}{c}\text { Creative } \\
\text { Elaboration }\end{array}$ & $\begin{array}{c}\text { Creative } \\
\text { Flexibility }\end{array}$ & $\begin{array}{c}\text { Creativity } \\
\text { Index }\end{array}$ \\
\hline \multirow{9}{*}{ Fluency } & \multirow{3}{*}{ NO of Words } & Pearson Correlation & $.510^{*}$ & $-.551^{*}$ & .328 & .194 & $.528^{*}$ \\
\hline & & Sig. (2-tailed) & .037 & .022 & .198 & .456 & .030 \\
\hline & & $\mathrm{N}$ & 32 & 32 & 32 & 32 & 32 \\
\hline & \multirow{3}{*}{ NO of T-units } & Pearson Correlation & $.590^{*}$ & -.345 & .276 & .311 & $.413^{*}$ \\
\hline & & Sig. (2-tailed) & .013 & .175 & .283 & .224 & .019 \\
\hline & & $\mathrm{N}$ & 32 & 32 & 32 & 32 & 32 \\
\hline & \multirow{3}{*}{ NO of Clauses } & Pearson Correlation & $.571^{*}$ & $-.416^{*}$ & .424 & .162 & $.548^{*}$ \\
\hline & & Sig. (2-tailed) & .017 & .047 & .089 & .533 & .025 \\
\hline & & $\mathrm{N}$ & 32 & 32 & 32 & 32 & 32 \\
\hline \multirow{6}{*}{ Complexity } & \multirow{3}{*}{ Clauses per T-unit } & Pearson Correlation & .313 & .176 & $.397^{*}$ & .384 & .407 \\
\hline & & Sig. (2-tailed) & .221 & .499 & .036 & .128 & .105 \\
\hline & & $\mathrm{N}$ & 32 & 32 & 32 & 32 & 32 \\
\hline & \multirow{3}{*}{$\begin{array}{l}\text { Dep. Clauses } \\
\text { Percentage }\end{array}$} & Pearson Correlation & .268 & -.180 & $.413^{*}$ & .063 & .438 \\
\hline & & Sig. (2-tailed) & .299 & .490 & .047 & .811 & .078 \\
\hline & & $\mathrm{N}$ & 32 & 32 & 32 & 32 & 32 \\
\hline \multirow{6}{*}{ Accuracy } & \multirow{3}{*}{$\begin{array}{l}\text { Error Free Clauses } \\
\text { Percentage }\end{array}$} & Pearson Correlation & -.060 & .212 & .435 & -.257 & .050 \\
\hline & & Sig. (2-tailed) & .818 & .414 & .081 & .320 & .848 \\
\hline & & $\mathrm{N}$ & 32 & 32 & 32 & 32 & 32 \\
\hline & \multirow{3}{*}{$\begin{array}{l}\text { Error Free T-units } \\
\text { Percentage }\end{array}$} & Pearson Correlation & .204 & .399 & .032 & .209 & .234 \\
\hline & & Sig. (2-tailed) & .433 & .112 & .903 & .422 & .367 \\
\hline & & $\mathrm{N}$ & 32 & 32 & 32 & 32 & 32 \\
\hline
\end{tabular}

*. Correlation is significant at the 0.05 level (2-tailed).

On the other hand, the correlation analysis reported in Table 5 shows negative relationships between the two measures of paired writings fluency and students' creative originality score (number of words $r=.47, p<0.05$; number of T-units $r=.51, p<0.05$; number of Clauses $r=$ $.51, p<0.05)$. In addition, Table 5 shows a non-significant and negative correlation between fluency of the text and creativity index. Unlike the individually written texts, there is no correlation between the fluency of the paired written texts and creative fluency.

As illustrated in Table 5, there is a positive correlation between one complexity measure (dep. clauses percentage $r=.45, p<0.05$ ) and creative elaboration. The other measure of complexity (clauses per T-unit) and none of the accuracy measures correlated with any of the creativity components. 
Table 5. Correlations between creativity and paired task performance

\begin{tabular}{|c|c|c|c|c|c|c|c|}
\hline Pair Essays & & & $\begin{array}{l}\text { Creative } \\
\text { Fluency }\end{array}$ & $\begin{array}{c}\text { Creative } \\
\text { Originality }\end{array}$ & $\begin{array}{c}\text { Creative } \\
\text { Elaboration }\end{array}$ & $\begin{array}{c}\text { Creative } \\
\text { Flexibility }\end{array}$ & $\begin{array}{c}\text { Creativity } \\
\text { Index }\end{array}$ \\
\hline \multirow{9}{*}{ Fluency } & \multirow{3}{*}{ NO of Words } & Pearson Correlation & .098 & $-.475^{*}$ & .063 & .080 & -.344 \\
\hline & & Sig. (2-tailed) & .700 & .046 & .803 & .752 & .163 \\
\hline & & $\mathrm{N}$ & 30 & 30 & 30 & 30 & 30 \\
\hline & \multirow{3}{*}{ NO of T-units } & Pearson Correlation & .232 & $-.510^{*}$ & .132 & .233 & -.296 \\
\hline & & Sig. (2-tailed) & .355 & .031 & .602 & .353 & .233 \\
\hline & & $\mathrm{N}$ & 30 & 30 & 30 & 30 & 30 \\
\hline & \multirow{3}{*}{ NO of Clauses } & Pearson Correlation & .153 & $-.515^{*}$ & .049 & .251 & -.329 \\
\hline & & Sig. (2-tailed) & .544 & .029 & .848 & .316 & .183 \\
\hline & & $\mathrm{N}$ & 30 & 30 & 30 & 30 & 30 \\
\hline \multirow{6}{*}{ Complexity } & \multirow{3}{*}{ Clauses per T-unit } & Pearson Correlation & .116 & .158 & .377 & .329 & .254 \\
\hline & & Sig. (2-tailed) & .647 & .531 & .096 & .182 & .309 \\
\hline & & $\mathrm{N}$ & 30 & 30 & 30 & 30 & 30 \\
\hline & \multirow{3}{*}{$\begin{array}{l}\text { Dep. Clauses } \\
\text { Percentage }\end{array}$} & Pearson Correlation & .110 & .248 & $.451^{*}$ & .335 & .330 \\
\hline & & Sig. (2-tailed) & .665 & .322 & .041 & .174 & .181 \\
\hline & & $\mathrm{N}$ & 30 & 30 & 30 & 30 & 30 \\
\hline \multirow{6}{*}{ Accuracy } & \multirow{3}{*}{$\begin{array}{l}\text { Error Free Clauses } \\
\text { Percentage }\end{array}$} & Pearson Correlation & .454 & .268 & .326 & .020 & .121 \\
\hline & & Sig. (2-tailed) & .058 & .282 & .187 & .936 & .632 \\
\hline & & $\mathrm{N}$ & 30 & 30 & 30 & 30 & 30 \\
\hline & \multirow{3}{*}{$\begin{array}{l}\text { Error Free T-units } \\
\text { Percentage }\end{array}$} & Pearson Correlation & .265 & .339 & -.023 & -.124 & .150 \\
\hline & & Sig. (2-tailed) & .288 & .169 & .929 & .625 & .552 \\
\hline & & $\mathrm{N}$ & 30 & 30 & 30 & 30 & 30 \\
\hline
\end{tabular}

*. Correlation is significant at the 0.05 level (2-tailed).

\section{Discussion and Conclusions}

With regards to the first research question, i.e. whether collaboration has any effect on the CAF of learners' written narrative task performance, the results showed that, among the three measures of task performance, i.e. complexity, accuracy and fluency, only accuracy is positively influenced by learners' collaboration. Simply put, the opportunity for collaborative writing resulted in more accurate written productions; this, in turn, justifies Vygotsky's (1978) contention that social interaction and collaboration enhances learning, at least in terms of accuracy (measured according to error-free T-units). This finding is consistent with the results of some other studies that have shown that learners' engagement in collaborative activities can enhance task performance in terms of accuracy (Nabei, 1996; Swain, 1998; Lapkin \& Swain 2000; Lapkin, Swain \& Smith, 2002). 
However, fluency (as measured by number of words in the text) of the performances was shown to be negatively related to paired task performance. This might be due to time limitations for performance; that is to say, the time spent on learners' collaboration might have hindered their writing fluency. Unlike the other two measures, however, the results for complexity measures (ratio of clauses to T-units and percentage of dependent clauses) failed to show a significant effect in paired task conditions, which seems to run counter to the results of other studies (e.g., Storch, 2005; Tuan \& Storch, 2007), almost all of which found that collaboration leads to more complex language use.

Regarding the second research question, i.e. whether there is any relationship between creativity and the CAF of individual L2 written narrative task performance, the ability of fluency constantly appears to make the most pronounced and constant association, in that three fluency measures of narrative task performance (number of words, number of T-units, number of clauses) in the individually performing group were found to positively correlate with creative fluency (Torrance, 1966) and with the total creativity score. This finding is in line with that obtained by Albert and Kormos (2011), who also indicated that learners who performed better on a creativity test were found to produce ideas more fluently in a narrative task. In the present study, the learners' creative fluency coincided with using more words, T-units, and clauses in the narrative task.

Since the participants were required to narrate a story based on some visual cues, it can be hypothesized that these learners had some unconventional ideas which they utilized while figuring out various events that might have occurred in the story; this, in turn, might have led to longer stories as the proposition of ideas needed further explanation. However, it was found that creative originality, or the extent to which learners are able to produce unique and unusual structures, was negatively correlated with some measures of performance fluency in the individually performed narrative task. This finding provides support for the claim made by Albert and Kormos (2011) and runs counter to a number of other studies (e.g., Ehrman \& Oxford, 1995; Grigorenko, Sternberg \& Ehrman, 2000) which have found that creative originality is an essential ability in defining language learning success. However, this finding is justifiable in that, in order to bring forth unique solutions to a problem, learners require a long period of contemplation, leading to fewer solutions on the whole. 
Moreover, results with regard to complexity measures reveal that the syntactic complexity of essays produced by individuals was related to creative elaboration, since the number of clauses per T-unit and dependent clauses percentage correlated positively with the elaboration measure of the creativity test. This finding might be due to the fact that creative elaboration, characterized by the number of details that the learner can add to the original idea, might be linked to learners' complex performance or, in Ellis' (2003) words, "the extent to which the language produced in performing a task is elaborate and varied" (p. 340).

Finally, as regards the third research questions, i.e. whether there is any relationship between creativity and the CAF of paired L2 written narrative task performance, correlation analysis shows negative relationships between the two measures of paired writings fluency and students' creative originality score (i.e. number of words, number of T-units and number of clauses). This finding is again justifiable given that learners need a long period of contemplation to provide unique solutions to a problem, hence the production of fewer solutions on the whole. In addition, the results show a non-significant and negative correlation between fluency of the text and the creativity index (CI). However, unlike the individually written texts, there is no correlation between the fluency of the paired written texts and creative fluency. These findings point to the fact that, due to time limitations for performance, the time spent on learners' collaboration could have hindered their writing fluency. Besides, there is a positive correlation between one complexity measure (dep. clauses percentage) and creative elaboration. The other measure of complexity (clauses per T-unit) and none of the accuracy measures correlated with any of the creativity components.

\section{Pedagogical Implications}

The findings of the present study do not seem to lend strong support to the presumed superiority of paired task performance through collaboration over individual task performance or the idea that paired tasks are necessarily more effective than individual tasks, though in the case of accuracy performance the results showed significant advantages for the collaborative task. Thus, the main implication of this study is that paired tasks in which learners collaboratively construct written texts may create opportunities for meaningful and purposeful communication, and 
engage them in producing more accurate texts, but not necessarily more creative ones (as measured by number of words, etc.).

In addition, the findings support the claim that creativity is a divisible construct and may consist of several components (Sternberg, 1985). For instance, among fluency, elaboration, originality, and flexibility, creative fluency was found to be correlated with measures of the individual narrative task but not with its paired-performed counterpart. Indeed, the findings obtained concerning the interface between creativity and measures of written task performance may contribute to making pedagogical decisions and can make materials developers, syllabus designers and language teachers revisit the selection and implementation of language teaching tasks. Accordingly, the professionals in the field of materials development ought to include definitive tasks in the textbooks with the purpose of enhancing learners' creativity. To give but one example, they may opt for including tasks which demand a considerable degree of imagination and generation of novel ideas. Yet there is a need for further study into why individuals write more fluently and then to see how these features can be integrated into other teaching tasks, including individual, pair and group work.

\section{References}

Albert, A . (2007). Creativity and task performance (Unpublished doctoral dissertation). Eotvos Lorand University, Budapest, Hungary.

Albert, A., \& Kormos, J. (2011). Creativity and narrative task performance: An exploratory study. Language Learning, 61, 73-99.

Amabile, T. M. (1996). Creativity in context. Boulder, CO: Westview Press.

Bakhtin, M. M. (1981). The dialogic imagination: Four essays. Austin \& London: University of Texas Press.

Carroll, J. B. (1993). Human cognitive abilities: A survey of factor analytic studies. Cambridge: Cambridge University Press.

Chen, S., \& Zhou, J. (2010). Creative writing strategies of young children: evidence from a study of Chinese emergent writing. Thinking Skills and Creativity, 5, 138-149.

Cole, M. (1996). Cultural psychology. A once and future discipline. Cambridge, MA: Harvard University Press.

Duffy, B. (1998). Supporting creativity and imagination in the early years. Buckingham: Open University Press.

Ehrman, M. E., \& Oxford, R. L. (1995). Cognition plus: Correlates of language learning success. Modern Language Journal, 79, 67-89. 
Ellis, R. (2003). Task-based language learning and teaching. Oxford: Oxford University Press.

Ellis, R. (2008). The study of second language acquisition. Oxford: Oxford University Press.

Ellis, R., \& Barkhuizen, G. (2005). Analyzing learner language. Oxford: Oxford University Press.

Ellis, R., \& Yuan, F. (2004). The effects of planning on fluency, complexity, and accuracy in second language narrative writing. Studies in Second Language Acquisition, 26(1), 59-84.

Foster, P., \& Skehan, P. (1996). The influence of planning and task type on second language performance. Studies in Second Language Acquisition, 18, 299-323.

Goff, K., \& Torrance, E. P. (2002). Abbreviated Torrance test for adults manual. Bensenville, IL: Scholastic Testing Service, Inc.

Grigorenko, E. L., Sternberg, R. J., \& Ehrman, M. E. (2000). A theory based approach to the measurement of foreign language learning ability: The Canal $\mathrm{F}$ theory and test. Modern Language Journal, 84, 390-405.

Guilford, J. P. (1950). Creativity. American Psychologist, 5, 444-454.

Guilford, J. P. (1959). Three faces of intellect. American Psychologist, 14, 469-479.

Harrington, D.M., Block, J., \& Block, J. H. (1983). Predicting creativity in preadolescence from divergent thinking in early childhood. Journal of Personality and Social Psychology, 45, 609-623.

Hilton, H. (2008). The link between vocabulary knowledge and spoken L2 fluency. Language Learning Journal, 36(2), 153-166.

Hunt, K. (1966). Recent measures in syntactic development. Elementary English, 43, 732-739.

Justice, L.M., Bowles, R., Pence, K., \& Gosse, C. (2010). A scalable tool for assessing children's language abilities within a narrative context The NAP (Narrative Assessment Protocol). Early Childhood Research Quarterly, 25, 218-234.

Kharkhurin, A.V. (2008). The effect of linguistic proficiency, age of second language acquisition, and length of exposure to a new cultural environment on bilinguals' divergent thinking. Bilingualism: Language and Cognition, 11(2), 225-243.

Kim, K.H. (2006). Can we trust creativity tests: A review of the Torrance Tests of Creative Thinking. Creativity Research Journal, 18, 3-14.

Lapkin, S. \& Swain, M. (2000). Task outcomes: A focus on immersion students' use of pronominal verbs in their writing. Canadian Journal of Applied Linguistics, 3, 7-22.

Lapkin, S., Swain, M., \& Smith, M. (2002). Reformulation and the learning of French pronominal verbs in a Canadian French immersion context. Modern Language Journal, 86, 485-507.

Larsen-Freeman, D. (2009). Adjusting expectations: The study of complexity, accuracy, and fluency in second language acquisition. Applied Linguistics, 30(4), 579-589.

Lin, W.L., Hsu, K.Y., Chen, H.C., \& Wang, J.W. (2011). The relations of gender and personality traits on different creativities: A dual-process theory account. Psychology of Aesthetics, Creativity, and the Arts. Advance online publication. doi:10.1037/a0026241

Lu, X. (2011). A Corpus-Based Evaluation of Syntactic Complexity Measures as Indices of College-Level ESL Writers' Language Development. Tesol Quarterly, 45(1), 36-62.

Meintjes, H., \& Grosser, M. (2010). Creative thinking in prospective teachers: the status quo and the impact of contextual factors. South African Journal of Education, 30, 361-386.

Nabei, T. (1996). Dictogloss: Is it an effective language learning task? Working Papers in Educational Linguistics, 12, 59-74. 
Norris, J. M., \& Ortega, L. (2009). Towards an organic approach to investigating CAF in instructed SLA: The case of complexity. Applied Linguistics, 30(4), 555-578.

Ozyildirim, I. (2009). Narrative analysis: An analysis of oral and written strategies in personal experience narratives. Journal of Pragmatics, 4, 1209-1222.

Pishghadam, R., \& Javdan Mehr, F. (2011). Learner creativity and performance in written narrative tasks. World Journal of Education, 1(2), 115-125.

Resnick, L., Pontecorvo, C., \& Saljo, R. (1997). Discourse, tools and reasoning. In L. Resnick, R. Saljo, C. Pontecorvo, \& B. Burge (Eds.), Discourse, tools and reasoning: Essays on situated cognition (pp. 1-20). Berlin and New York: Springer-Verlag.

Robinson, P. (1995). Task complexity and second language narrative discourse. Language Learning, 45, 99-140.

Rogoff, B., Turkanis, C., \& Bartlett, L. (Eds.). (2001). Learning together: Children and adults in a school community. London: Oxford University Press.

Rojas-Drummond, S. M., Albarran, C. D., \& Littleton, K. S. (2008). Collaboration, creativity and the co-construction of oral and written texts. Thinking Skills and Creativity, 3(3), 177-191.

Runco, M. A., Dow, G. T., \& Smith, W. R. (2006). Information, experience, and divergent thinking: An empirical test. Creativity Research, 18, 269-277.

Sak, U. (2004). About creativity, giftedness, and teaching the creatively gifted in the classroom. Roeper Review, 26(4), 216.

Scanlon, J. (2006). Reading, writing, and creativity. Business Week Online, 00077135, 2/23/2006, p. 10.

Sharples, M. (1999). How we write-Writing as creative design. London: Routledge.

Skehan, P. (2009). Modeling second language performance: Integrating complexity, accuracy, fluency, and lexis. Applied Linguistics, 30(4), 510-532.

Smith, D. K., Paradice, D. B., \& Smith, S. M. (2000). Prepare your mind for creativity. Communications of the ACM, 43(7), 110-116.

Sternberg, R. J. (1985). Implicit theories of intelligence, creativity, and wisdom. Journal of Personality and Social Psychology, 49, 607-627.

Storch, N. (2005). Collaborative writing: Product, process, and students' reflections. Journal of Second Language Writing, 14(3), 153-173.

Swain, M. (1998). Focus on form through conscious reflection. In C. Doughty \& J. Williams (Eds.), Focus on form in classroom second language acquisition (pp. 64-81). Cambridge: Cambridge University Press.

Torrance, E. P. (1966). The Torrance tests of creative thinking-norms-technical manual research edition-verbal tests, forms $A$ and B-figural tests, forms $A$ and B. Princeton, NJ: Personnel Press.

Torrance, E. P. (1992). A national climate for creativity and invention. Gifted Child Today, 15(1), 10-14.

Torrance, E. P. (Ed.). (2000). On the edge and keeping on the edge. Bensenville, IL: Scholastic Testing Service, Inc.

Tuan, T. A., \& Storch, N. (2007). Investigating group planning in preparation for oral presentations in an EFL class in Vietnam. RELC Journal, 38(1), 104-124.

Vass, E. (2007). Exploring processes of collaborative creativity-The role of emotions in children's joint creative writing. Thinking Skills and Creativity, 2, 107-117.

Vygotsky, L. S. (1978). Mind in society. Cambridge: Harvard University Press. 
Wang, A. Y. (2011). Contexts of creative thinking: A comparison on creative performance of student teachers in Taiwan and the United States. Journal of International and Crosscultural Studies, 2(1), 1-14.

Wegerif, R., \& Mercer, N. (1997). A dialogical framework for researching peer talk. In R. Wegerif \& P. Scrimshaw (Eds.), Computers and talk in the primary classroom (pp. 49-64). Clevedon: Multilingual Matters.

Wertsch, J. V. (1991). Voices of the mind. A sociocultural approach to mediated action. Cambridge, MA: Harvard University Press.

Wigglesworth, G., \& Storch, N. (2009). Pair versus individual writing: Effects on fluency, complexity and accuracy. Language Testing, 26(3) 445-466.

Wolfe-Quintero, K., Inagaki, S., \& Kim, H. Y. (1998). Second language development in writing: Measures of fluency, accuracy, and complexity. Hawaii: University of Hawaii, Second Language Teaching and Curriculum Center.

\section{Authors' References:}

Reza Zabihi is a PhD candidate of Applied Linguistics at University of Isfahan, Iran. He is also a member of Iran's National Elites Foundation (INEF). His major research interests include issues in language teaching/learning, syllabus design, positive psychology, happiness studies, and life skills education.

Mohsen Rezazadeh is a Ph.D. candidate at University of Isfahan, Iran. His main research interests are in the areas of EFL teaching and learning, language testing and assessment, and psycholinguistics. He has published several articles in his areas of interest.

Hossein Vahid Dastjerdi is an Associate Professor of Applied Linguistics, University of Isfahan, Iran. He has taught courses at this university for more than 15 years. His research interests are in the area of Discourse and translation, DA and CDA, Discourse and TEFL, Multicultural discourses and Discourse and the media.

\section{Principal correspondent's email:}

zabihi@hotmail.com

To cite this article:

Zabihi, R., Rezazadeh, M,, \& Vahid Dastjerdi, H. (2013). Creativity and narrative writing in L2 classrooms: Comparing individual and paired task performance. Bellaterra Journal of Teaching \& Learning Language \& Literature, 6(3), 29-46. 